This document is the accepted manuscript version of the following article:

Wermelinger, B., Obrist, M. K., Baur, H., Jakoby, O., \& Duel1i, P. (2013). Synchronous rise and fall of bark beetle and parasitoid populations in windthrow areas. Agricultural, and Forest Entomology, 15(3), 301-309. https://doi.org/10.1111/afe.12018

\title{
Synchronous rise and fall of bark beetle and parasitoid populations in windthrow areas
}

B. Wermelinger ${ }^{1}$, M.K. Obrist ${ }^{1}$, H. Baur ${ }^{2}$, O. Jakoby ${ }^{1}$, P. Duelli ${ }^{1}$

${ }^{1}$ Swiss Federal Institute for Forest, Snow and Landscape Research WSL, Zürcherstrasse 111, 8903 Birmensdorf, Switzerland

${ }^{2}$ Natural History Museum Bern, Bernastrasse 15, 3005 Bern, Switzerland

Correspondence: Beat Wermelinger, Swiss Federal Institute for Forest, Snow and Landscape Research WSL, Zürcherstrasse 111, 8903 Birmensdorf, Switzerland tel +41 4473922 58, fax +414473922 15, mail beat.wermelinger@wsl.ch

Running title: Bark beetle and parasitoid dynamics in windthrows

Keywords: Bark beetles, Ips typographus, parasitoids, predatory beetles, Pteromalidae, succession, synchrony, timber harvest, time lag, windthrow

\section{Abstract}

1 Windthrows in spruce forests provide a prime substrate for the population build-up of bark beetles. Until now, no information has been available on the population development of associated parasitoids.

2 The development of bark beetle and parasitoid populations was monitored on cleared and uncleared windthrow areas for 4 years, corresponding to the second to fifth growing seasons after the storm.

3 The population level of both groups quickly increased synchronously from the second to the third season, and gradually declined thereafter until the fifth growing season. The parasitoids showed no time lag.

4 At the species level, the same pattern was found for the pest Ips typographus (L.) and its specific parasitoid Dinotiscus eupterus (Walk.).

5 During the 4 years under study, a succession of different bark beetle and parasitoid species was found. 
6 Bark beetles and parasitoids were more abundant on uncleared windthrow areas than on cleared areas, while predatory beetles generally preferred the adjacent forest.

7 Once the deteriorated phloem quality precludes further bark beetle development, no more bark beetle-relevant parasitoids are produced in windthrows.

\section{Introduction}

Bark beetles (Curculionidae, Scolytinae) are ecological and economic key players in coniferous forests all over the world. From an ecological point of view, they are pioneers that colonize newly dead or moribund trees and initialize their decomposition. A few notorious pest species are known to be able to kill large numbers of living host trees and thus have an economic impact (e.g. Schelhaas et al., 2003; Grégoire \& Evans, 2004; Wermelinger, 2004; Safranyik et al., 2010). Of these, the European spruce bark beetle Ips typographus (L.) is one of the most significant forest pests in Europe. Large-scale outbreaks of this beetle are typically triggered by vast windthrows in spruce forests, such as those in the wake of the recent storms 'Vivian' in 1990 (Forster et al., 2011), 'Lothar' in 1999 (Gugerli et al., 2008), 'Gudrun' in 2005 (Komonen et al., 2011), and 'Kyrill' in 2007 (Steyrer \& Krehan, 2011).

The development of bark beetle populations is affected by, among other drivers, a wide range of parasitoid and predatory arthropod natural enemies. The composition of the antagonistic complex and the biology of the key species have been quite well documented (Kenis et al., 2004). They have been reported to inflict significant bark beetle mortality (Raffa, 1991; Dippel et al., 1997; Wermelinger, 2002), although exactly how much impact these natural enemies have on bark beetle infestation dynamics is still a matter of debate (Reeve, 1997; Wermelinger, 2004) because their impact during an outbreak is usually blurred by other important influences. These include: intraspecific competition (Anderbrant et al., 1985; Wallin et al., 2008; Faccoli \& Bernardinelli, 2011; Komonen et al., 2011), host tree resistance (Berryman, 1982; 
Lieutier, 2004; Wallin et al., 2008) and human control measures (Grodzki et al., 2006; Faccoli \& Stergulc, 2008).

A large volume of literature exists on the theory of predator/prey and parasitoid/host population interactions (Mills \& Getz, 1996). Typically, the response of parasitoid populations is assumed to be time-lagged with respect to the host populations, although suitable field data supporting this theory are largely lacking. So far, most quantitative research on the topic has been conducted in a snapshot manner, with study periods of 1 year at most. Only a few studies have produced quantitative data on the multiseasonal development of host and parasitoid populations (Moore, 1972; Lobinger \& Feicht, 1999; Wermelinger, 2002; Markovic \& Stojanovic, 2003) and these have focused on attacked stands with living trees. Although bark beetle populations are known to thrive in uncleared windthrow areas, no information is available on the effects of these areas on the beetles' natural enemies. In such a habitat, the development of host/parasitoid interactions remains largely unaffected by tree resistance or human control measures.

After the large-scale windthrow caused by 'Vivian' in 1990, a project on the longterm development of insect communities in subalpine spruce forests was started in Switzerland (Duelli et al., 2002; Wermelinger et al., 2002), which is still ongoing. This project provides a unique data set of multiseasonal catches of bark beetles and parasitoids, which is analyzed in detail in the present study. We examined the population dynamics and growth rates during the first 4 years after the storm of both hosts and parasitoids in general, as well as of specific species. In particular, we investigated whether time-lagged bark beetle/parasitoid dynamics could develop in an ephemeral substrate such as that provided by windthrown timber. Furthermore, we analyze the succession of the prevailing host and parasitoid species after the storm, before finally drawing conclusions about the effects of timber clearing on the abundance of bark beetles, parasitoids and predators. 


\section{Materials and Methods}

Study sites and insect sampling

After the hurricane 'Vivian' on 26/28 February 1990, three sites with extensive windthrow damage were selected for long-term study in subalpine spruce forests in the Swiss Prealps, namely Pfäfers (46.97 N 9.49E;1450 m a.s.I.), Schwanden $\left(46.99^{\circ} \mathrm{N} 9.08^{\circ} \mathrm{E} 1100 \mathrm{~m}\right.$ a.s.I.), and Disentis $\left(46.68^{\circ} \mathrm{N} 8.83^{\circ} \mathrm{E} ; 1450 \mathrm{~m}\right.$ a.s.I.). The western-oriented stands were composed of 70-150-year-old spruce (Picea abies [L.] Karst.) trees with some Larix decidua Mill. and Abies alba Mill. (Pfäfers site) and Fagus sylvatica L. and Acer pseudoplatanus L. (Schwanden site). Because of the high altitude, wood decomposition and tree regeneration were very slow during the first years after windthrow. Each of the three sites comprised a cleared and an uncleared plot of 1-3 ha each [i.e. plots with and without timber harvest (treatments)]. Timber (but not the stumps and fine woody debris) (Priewasser et al., 2012) was removed from the cleared plots during summer 1990, while the fallen trees were left untouched in the uncleared plots. At Schwanden, an adjacent intact forest stand was included in the study as a control treatment. The characteristics of the sites are described in more detail in Schönenberger (2002). Three flight interception traps were mounted on each plot in a triangular alignment at distances of 25-75 $\mathrm{m}$. The glass panes were oriented to be $60^{\circ}$ offset from each other to exclude a possible influence of the wind directions. The traps consisted of vertical glass panes $(80 \times 50$ $\mathrm{cm}$ ) supported by a wooden frame, with two trays filled with water, some traces of detergent and a biocide ( $0.2 \%$ Rocima GT; Acima, Switzerland) on either side of the pane (Duelli et al., 1999; Wermelinger et al., 2002). Between 1991 and 1994, the 21 traps ( 3 sites $\times 2$ treatments $\times 3$ traps +3 traps in the intact forest) were operated from May to September each year, during which period they were emptied and serviced weekly. Hereafter, we will refer to 'growing season' rather than 'year', with 1990 counting as the first growing season (S1) after the storm. Growing season number also corresponds to the generation number of the univoltine bark beetle populations produced after the storm.

\section{Data editing}

For the present study, only the catches from May to July were analyzed for two reasons: First, given the altitude of our study sites, bark beetle and parasitoid populations were univoltine (Forster et al., 2003). Second, previous studies at one of 
the study sites had revealed that, at this altitude, a sizeable fraction of their populations leave their brood trees in fall in search for other overwintering sites (Wermelinger et al., 2012). Therefore, the swarming of such individuals was recorded twice: once in the autumn and again in the spring when re-emerging from the overwintering sites searching for brood trees. To be able to correctly compare population sizes of corresponding bark beetle and parasitoid generations, the catches were restricted to May-July, thus capturing only one flight of each generation. However, for the phenologies, we used all available data to show the complete flight activities during the seasons. It should be stressed that, for univoltine populations, the catches in a given growing season represent the reproductive success of the previous growing season [i.e. the beetles captured in the spring of, for example, the second growing season (1991) after the storm were produced in the first growing season (1990)].

Parasitoid and predatory species were selected according to the list of European natural enemies of bark beetles (Kenis et al., 2004). Because predatory beetles were identified only from 1993 and 1994 (i.e. growing seasons 4 and 5= S4, S5), temporal analyses were performed with bark beetles and parasitoids only. The predators were included, however, in the evaluation of clearing treatment effects. The insect taxonomy follows the 'Fauna Europaea' online database (Fauna Europaea Web Service, 2012).

\section{Statistical analysis}

The statistical analyses were performed using the statistical computing system $R$, version 2.13.0 (R Development Core Team, 2011). We used linear mixed-effects models (Ime; package nlme; Pinheiro et al., 2012) to test for differences in the seasonal growth rates of bark beetles and parasitoids, as well as habitat (=treatment) preferences of bark beetles, parasitoids and predators. Linear mixed-effects models (Zuur et al., 2009) are able to analyze clustered data that are not statistically independent, e.g. repeated sampling over time or at multiple locations. Population growth rates [log $\left(\mathrm{P}_{t+1} / \mathrm{P}_{\mathrm{t}}\right)$; where $\mathrm{t}=$ growing seasons $\left.2-4\right]$ were calculated for each season $t$ and each plot. Insect group and season served as fixed effects, with site as random effect. Habitat preferences are based on data collected at the Schwanden site in growing seasons 4 and 5 . Here, year and trap were used as random effects, with treatment as a fixed effect. 


\section{Results}

\section{Species numbers and abundances}

The species of bark beetles and natural enemies used in this analysis are listed in the Appendix 1. In total, we recorded 485 individuals from 14 species of predatory beetles (from only two growing seasons, S4 and S5), 951 from 12 parasitoid species, and 45392 from 35 species of bark beetles. The bark beetles were dominated by Pityogenes chalcographus (29\% of all bark beetles), a potentially detrimental species that develops mainly in small-diameter logs and branches. Among the other potential pest species, the notorious pest $I$. typographus accounted for $10 \%$ of the bark beetles, and Trypodendron lineatum accounted for 9\%. Among the antagonists, the nitidulid beetle Pityophagus ferrugineus was the most abundant predator (33\%) and the pteromalid wasp Dinotiscus eupterus (63\%) the most frequent parasitoid.

Several antagonistic groups were excluded from the analysis because they were present either in only small numbers or in an inconsistent way. For completeness, they comprised 16 individuals from two Corticeus species (Tenebrionidae); 29 Nemozoma elongatum (L.) (Trogositidae); 51 Nudobius lentus (Grav.); two Phloeonomus species (Staphylinidae); 26 individuals mostly from Cosmophorus, Dendrosoter and Ropalophorus (Braconidae); 90 Xylocoris cursitans (Fall.) (Anthocoridae); and 115 Phaeostigma notata (F.) (Raphidiidae).

\section{Multiseasonal population dynamics}

Both bark beetle hosts and their associated parasitoids showed very similar abundance dynamics at all sites after the storm (Fig. 1). The catches of bark beetles generally peaked in the third growing season after the storm (site Disentis: fourth season), before declining in the fifth growing season to a level similar to that at the beginning of the population increase. The same pattern of two seasons with elevated populations was found for the parasitoids. The population increases of bark beetles and parasitoids followed a similar pattern, starting for both guilds at very low levels. The regulation of bark beetles by parasitoids depends on the velocity of the 
population growth rates of the natural enemies relative to that of the bark beetles. The yearly population growth rates of bark beetles and parasitoids on windthrow areas are depicted in Fig. 2. In the second growing season after the storm, the populations of the hosts multiplied on average by a factor of six (i.e. the multiplication rate from second to third season), although those of the parasitoids were three-fold higher (d.f. $=26, p=0.0065$ ). The population levels of the next generations in the subsequent growing season remained stable in both groups, whereas, from the fourth to the fifth season, both groups declined at an approximately equal rate. At the species level, a similar pattern could be observed for the pest bark beetle $I$. typographus and the most abundant parasitoid D. eupterus (Fig. 3), a typical parasitoid of I. typographus (Kenis et al., 2004). Both species increased and decreased in population size in synchrony, and there was no time lag for the parasitoid at the beginning.

\section{Flight phenology}

The multiseasonal flight phenology of bark beetles and parasitoids was evaluated for the Pfäfers site, which provided the most extensive data. Fig. 4 shows that the annual flight behavior of $I$. typographus differed from that of its parasitoids. The high populations of both groups in the third and fourth growing season are again clearly visible. The flight times of $I$. typographus and its parasitoids differed each year and, after overwintering, the emerging bark beetles preceded the parasitoids by 2-5 weeks. By contrast to I. typographus, the parasitoids flew for a markedly longer period up to the end of September in what appear to be two main waves, one after the emergence of $I$. typographus and one in late summer.

\section{Species succession}

Depending on the species, bark beetles prefer different qualities (humidities) of bark. This, together with the varied population growth capacities of the different species, leads to a succession of species during the decay process of bark and wood in the windthrown timber. This succession is illustrated for six of the most abundant bark beetle and parasitoid species, respectively (Fig. 5). The species that responded most rapidly and markedly to the ample supply of fresh bark was $P$. chalcographus. Its populations multiplied almost 20 -fold from the second to the third growing season, 
but then thereafter gradually declined to almost zero in the fifth season. Ips typographus showed a similar but less dramatic pattern, as did the striped ambrosia beetle ( $T$. lineatum), which develops in the sapwood rather than in the bark. These species were replaced in the fourth growing season by the two very abundant phloem feeders Dryocoetes autographus and Crypturgus pusillus. The ambrosia beetle Xyleborus dispar was rarely present before the fifth growing season.

The parasitoids that depend on specific bark beetle hosts may have an analogous species succession. Three of the important parasitoids (Roptrocerus mirus, Rhopalicus tutela and $D$. eupterus) had, similar to their hosts (mainly I. typographus and $P$. chalcographus), maximum population densities in the third growing season after the storm. They were followed by the little-known Macromesus amphiretus, a parasitoid of $P$. chalcographus, and the most abundant parasitoid, namely Roptrocerus brevicornis. The populations of the rather infrequent Platygerrhus affinis quickly increased and then remained at a constantly high level throughout the 4-year period. This species also parasitizes hosts other than bark beetles (Noyes, 2011).

\section{Effect of timber harvest}

Because salvage logging of the fallen timber might affect bark beetles and their natural enemies in different ways, their relative distribution on cleared and uncleared areas, as well as in an adjacent forest unaffected by the storm, were compared. The Schwanden site was chosen for comparison as it is the only site where an intact forest habitat was also sampled. To include all available data on predatory beetles (Appendix SI), only the 2 last years (i.e. growing seasons 4 and 5) could be considered because the catches of the first 2 years had not been identified.

Although bark beetles and parasitoids were quite clearly more abundant in uncleared windthrows than in cleared plots or in the intact forest (Fig. 6), most predatory beetles preferred the closed forest over both the cleared and uncleared windthrow areas. An exception was the clerid Thanasimus formicarius, which was more abundant on windthrow areas. Moreover, the 90 specimens of the predatory heteropteran $X$. cursitans were found exclusively in windthrows (data not shown). The number of species of bark beetles and predatory beetles did not differ between 
treatments. Similar to their abundance, the number of species of parasitoids was markedly smaller in the forest (three species) than in the windthrows (nine species).

\section{Discussion}

\section{Parasitoid/host dynamics}

Windthrown coniferous trees are an ephemeral substrate that support bark beetle development for a limited period of time. Depending on temperature, air humidity, altitude, insolation, and slope, the tree phloem gradually desiccates and eventually becomes detached from the trunk. Thus, the population dynamics of bark beetles may be governed by both resource availability and parasitoid/host interactions, which makes it difficult to interpret. The results of the present study show that host and parasitoid populations increased and declined rather synchronously. The relatively few bark beetles present immediately after the storm took advantage of the ample breeding substrate and produced many offspring, which immediately served as hosts for the parasitoids (functional and numerical response). No time lag of parasitoid population development was apparent, which goes against the classical parasitoid/host theory of population cycling. The populations started from the beginning with similar growth rates. On average, the populations of parasitoids grew even faster at the beginning than those of the bark beetles (Fig. 2). At the species level, the population dynamics of the pest $I$. typographus and its parasitoid $D$. eupterus (Fig. 3) matched those of the parasitoids and bark beetles in general (Fig. 1): Again, no time lag in the multiseasonal development of the parasitoid generations was apparent. Synchronous population dynamics have been described for another predator beetle/bark beetle system (Reeve, 1997), and positive correlations between hosts and parasitoids have been reported (Gargiullo \& Berisford, 1981; Wermelinger, 2002), as well as with other types of disturbance (Mateos et al., 2011).

\section{Bark quality drives population dynamics}

The abundance of parasitoids is quite small compared with that of bark beetles. Of course, other mortality agents acting on bark beetles such as predators or fungi also play a role in their population dynamics (Keller et al., 2004). The little data available 
on predators (Appendix SI) shows a population decrease from the fourth and fifth growing season similar to that of bark beetles and parasitoids. Thus, the decline of bark beetles after the third growing season is probably more resource-driven than the result of natural enemy control. The desiccating phloem becomes increasingly unsuitable for most bark beetles, and their offspring production decreases. Thus hosts for parasitization become scarcer. Windthrows that have become unsuitable for bark beetle development after some years no longer provide habitat for bark beetlerelevant parasitoids.

Our findings show that windthrown spruce trees in subalpine forests support bark beetle development for three growing seasons (Wermelinger et al., 1999; Göthlin et al., 2000). In the fourth season, many offspring initiated in the previous year will still be caught in the traps, but they seem to lack sufficient suitable breeding resources and therefore fewer progeny emerge in growing season 5. Some of the populations may also emigrate (Duelli et al., 1997) or switch to attacking weakened but still standing trees outside the windthrow areas (Wermelinger, 2004; Komonen et al., 2011). At lower altitudes, this time-window for colonization of windthrown timber is shorter, amounting to only 1 or 2 years (Schroeder, 2001; Komonen et al., 2011). This characteristics differ from other bark and wood boring insects, such as cerambycid beetles, a group that has been found to increase both in species number and abundance during the first 10 years after the storm (Wermelinger et al., 2002).

Even though the Disentis site was the largest uncleared area with ample breeding substrate, the bark beetle populations that developed here were markedly smaller than at the two other sites (Fig. 1), probably due to the small background populations at the time before the storm. One year before the storm, salvage cuttings of $I$. typographus-infested spruce amounted to $0.08 \mathrm{~m}^{3} /$ ha in the Disentis region, whereas, at Schwanden, they amounted to $2 \mathrm{~m}^{3} /$ ha (personal communication W. Müller, J. Walcher).

\section{Intra- and inter-annual successions}

Two characteristics of the seasonal development of $I$. typographus and parasitoids are particularly worthy of note (Fig. 4). First, all parasitoid species emerged consistently later in the season than the spruce bark beetles, as has been described previously (Aukema et al., 2004; Wermelinger et al., 2012). Second, in contrast to $I$. 
typographus, the flight period of the parasitoid species extends throughout the entire growing season as a result of the different flight times of the different species parasitizing particular hosts, summarized as one curve. In addition to the intra-annual sequences of species, an inter-annual succession of host and parasitoid species also occurs (Fig. 5). The bark beetle species known to also attack living trees (i.e. the potential pest species) were the first to colonize the windthrown logs. Interestingly, $X$. dispar, which preferably colonizes fresh hardwood, appeared as a late-succession species. However, this finding is mostly the result of it being present in high numbers in growing season 5 at Schwanden (Appendix SI). At this site, scattered deciduous trees (Fagus sylvatica) had survived the storm but suffered in its aftermath.

\section{Effects of timber harvest}

Predatory beetles and parasitoids seem to have different environmental requirements. The parasitoids in our study had exactly the same habitat preferences as their bark beetle hosts (i.e. they were most abundant on uncleared windthrows with abundant breeding resources). On cleared areas or in the forest, bark beetles and parasitoids were infrequent. Parasitoid activity may depend not only on host availability, but also on the openness of the habitats. Open windthrows with flowering vegetation provide nectar, which is essential for the egg maturation of some parasitoid species (Drumtra \& Stephen, 1999; Hougardy \& Grégoire, 2000). The general preference pattern of parasitoids may vary with species.

By contrast to parasitoids, most predators preferred the forest habitat to the open windthrow areas. Obviously, these predators also feed on other prey besides bark beetles and do not depend on nectar. However, the clerid beetle T. formicarius tended to prefer the open windthrow habitats, as also reported by Hilszczanski et al. (2007). The proportions of bark beetles and parasitoids in cleared and uncleared windthrows were the same; thus, the salvage logging of windthrows did not appear to negatively affect the interactions between bark beetles and their natural enemies. Similarly, sanitation felling of infested living trees has been reported to have very few negative effects on natural enemy populations (Feicht, 2004; Hilszczanski et al., 2007), although the timing of such measures may well affect the impact of antagonists (Wermelinger et al., 2012). 


\section{Conclusions}

In conclusion, after a storm, it appears that both bark beetle and parasitoid populations are able to exploit the resulting ephemeral breeding resources very rapidly and synchronously. The rate of deterioration of the phloem quality appears to be more important in driving their population dynamics than the parasitoid/host interactions. Our findings indicate that windthrows in subalpine spruce forests support bark beetle development up to three growing seasons after a storm and then become unsuitable for breeding in the fourth year. By the same token, after this period, windthrown logs are no longer a source of bark beetle-relevant parasitoids. A fraction of the bark beetle populations may then move to adjacent forest edges and attack standing trees.

\section{Acknowledgements}

The extensive field work was assisted by T. Affolter, B. Fecker, M. Frech, M. Plattner and P. Wirz. We are also grateful to D. Schneider Mathis, M. Knízek and P. Zahradnik for their help with beetle identification and to S. Dingwall for reviewing the English.

\section{References}

Anderbrant, O., Schlyter, F. \& Birgersson, G. (1985) Intraspecific competition affecting parents and offspring in the bark beetle Ips typographus. Oikos, 45, 89-98.

Aukema, B.H., Richards, G.R., Krauth, S.J. \& Raffa, K.F. (2004) Species assemblage arriving at and emerging from trees colonized by Ips pini in the Great Lakes region: Partitioning by time since colonization, season, and host species. Annals of the Entomological Society of America, 97, 117-129.

Berryman, A.A. (1982) Biological control, thresholds, and pest outbreaks. Environmental Entomology, 11, 544-549.

Dippel, C., Heidger, C., Nicolai, V. \& Simon, M. (1997) The influence of four different predators on bark beetles in European forest ecosystems (Coleoptera: Scolytidae). Entomologia Generalis, 21, 161-175. 
Drumtra, D.E.W. \& Stephen, F.M. (1999) Incidence of wildflower visitation by hymenopterous parasitoids of southern pine beetle, Dendroctonus frontalis Zimmermann. Journal of Entomological Science, 34, 484-488.

Duelli, P., Obrist, M.K. \& Schmatz, D.R. (1999) Biodiversity evaluation in agricultural landscapes: above-ground insects. Agriculture, Ecosystems \& Environment, 74, 33-64.

Duelli, P., Obrist, M.K. \& Wermelinger, B. (2002) Windthrow-induced changes in faunistic biodiversity in alpine spruce forests. Forest Snow and Landscape Research, 77, 117-131.

Duelli, P., Zahradnik, P., Knizek, M. \& Kalinova, B. (1997) Migration in spruce bark beetles (Ips typographus L.) and the efficiency of pheromone traps. Journal of Applied Entomology, 121, 297-303.

Faccoli, M. \& Bernardinelli, I. (2011) Breeding performance of the second generation in some bivoltine populations of Ips typographus (Coleoptera Curculionidae) in the south-eastern Alps. Journal of Pest Science, 84, 15-23.

Faccoli, M. \& Stergulc, F. (2008) Damage reduction and performance of mass trapping devices for forest protection against the spruce bark beetle, Ips typographus (L.) (Coleoptera Curculionidae Scolytinae). Annals of Forest Science, 65, 309.

Fauna Europaea Web Service (2012) Fauna Europaea version 2.5. http://www.faunaeur.org.

Feicht, E. (2004) Parasitoids of Ips typographus (Col., Scolytidae), their frequency and composition in uncontrolled and controlled infested spruce forest in Bavaria. J. Pest Sci., 77, 165-172.

Forster, B., Meier, F. \& Rigling, A. (2011) Bark beetles and meteorological events. Proc. 10th IUFRO Workshop WP 7.03.10: Biotic Risks and Climate Change in Forests. Berichte Freiburger Forstliche Forschung, 89, 13-17.

Forster, B., Meier, F. \& Zahn, C. (2003) Erfahrungen im Umgang mit BuchdruckerMassenvermehrungen (Ips typographus L.) nach Sturmereignissen in der Schweiz. Schweizerische Zeitschrift für Forstwesen, 154, 431-436.

Gargiullo, P.M. \& Berisford, C.W. (1981) Effects of host density and bark thickness on the densities of parasites of the southern pine beetle. Environmental Entomology, 10, 392-399.

Göthlin, E., Schroeder, L.M. \& Lindelow, A. (2000) Attacks by Ips typographus and Pityogenes chalcographus on windthrown spruces (Picea abies) during the two years following a storm felling. Scandinavian Journal of Forest Research, 15, 542-549.

Grégoire, J.C. \& Evans, H.F. (2004) Damage and control of BAWBILT organisms an overview. Bark and wood boring insects in living trees in Europe - a synthesis (ed. by F. Lieutier, K.R. Day, A. Battisti, J.C. Grégoire and H.F. Evans), pp. 19-37. Kluwer Academic Publishers, Dordrecht.

Grodzki, W., Jakus, R., Lajzova, E., Sitkova, Z., Maczka, T. \& Skvarenina, J. (2006) Effects of intensive versus no management strategies during an outbreak of the bark beetle Ips typographus (L.) (Col.: Curculionidae, Scolytinae) in the Tatra Mts. in Poland and Slovakia. Annals of Forest Science, 63, 55-61.

Gugerli, F., Gall, R., Meier, F. \& Wermelinger, B. (2008) Pronounced fluctuations of spruce bark beetle (Scolytinae: Ips typographus) populations do not invoke genetic differentiation. Forest Ecology and Management, 256, 405-409. 
Hilszczanski, J., Gibb, H. \& Bystrowski, C. (2007) Insect natural enemies of Ips typographus (L.) (Coleoptera, Scolytinae) in managed and unmanaged stands of mixed lowland forest in Poland. Journal of Pest Science, 80, 99-107.

Hougardy, E. \& Grégoire, J.C. (2000) Spruce stands provide natural food sources to adult hymenopteran parasitoids of bark beetles. Entomologia Experimentalis et Applicata, 96, 253-263.

Keller, S., Epper, C. \& Wermelinger, B. (2004) Metarhizium anisopliae as a new pathogen of the spruce bark beetle Ips typographus. Mitteilungen der Schweizerischen Entomologischen Gesellschaft, 77, 121-123.

Kenis, M., Wermelinger, B. \& Grégoire, J.C. (2004) Research on parasitoids and predators of Scolytidae - a review. Bark and wood boring insects in living trees in Europe - a synthesis (ed. by F. Lieutier, K.R. Day, A. Battisti, J.C. Grégoire and H.F. Evans), pp. 237-290. Kluwer Academic Publishers, Dordrecht.

Komonen, A., Schroeder, L.M. \& Weslien, J. (2011) Ips typographus population development after a severe storm in a nature reserve in southern Sweden. Journal of Applied Entomology, 135, 132-141.

Lieutier, F. (2004) Host resistance to bark beetles and its variations. Bark and wood boring insects in living trees in Europe - a synthesis (ed. by F. Lieutier, K.R. Day, A. Battisti, J.-C. Grégoire and H.F. Evans), pp. 135-180. Kluwer Academic Publishers, Dordrecht.

Lobinger, G. \& Feicht, E. (1999) Schwärmverhalten und Abundanzdynamik der Erzwespe Karpinskiella pityophthori (Bouček) (Hym., Pteromalidae), eines Parasitoiden des Kupferstechers (Pityogenes chalcographus L., Col., Scolytidae). Journal of Pest Science, 72, 65-71.

Markovic, C. \& Stojanovic, A. (2003) Significance of parasitoids in the reduction of oak bark beetle Scolytus intricatus Ratzeburg (Col., Scolytidae) in Serbia. Journal of Applied Entomology, 127, 23-28.

Mateos, E., Santos, X. \& Pujade-Villar, J. (2011) Taxonomic and functional responses to fire and post-fire management of a Mediterranean Hymenoptera community. Environmental Management, 48, 1000-1012.

Mills, N.J. \& Getz, W.M. (1996) Modelling the biological control of insect pests: a review of host-parasitoid models. Ecological Modelling, 92, 121-143.

Moore, G. (1972) Southern pine beetle mortality in North Carolina caused by parasites and predators. Environmental Entomology, 1, 58-65.

Noyes, J.S. (2011) Universal Chalcidoidea database. World Wide Web electronic publication. http://www.nhm.ac.uk/chalcidoids.

Pinheiro, J.C., Bates, D.M., DebRoy, S., Sarkar, D. \& R Development Core Team (2012) nlme: Linear and Nonlinear Mixed Effects Models. R package version 3.1-103.

Priewasser, K., Brang, P., Bachofen, H., Bugmann, H. \& Wohlgemuth, T. (2012) Impacts of salvage-logging on the status of deadwood after windthrow in Swiss forests. European Journal of Forest Research (in press).

R Development Core Team (2011). R: A language and environment for statistical computing. R Foundation for Statistical Computing, Vienna, Austria.

Raffa, K.F. (1991) Temporal and spatial disparities among bark beetles, predators, and associates responding to synthetic bark beetle pheromones: Ips pini (Coleoptera: Scolytidae) in Wisconsin. Environmental Entomology, 20, 16651679. 
Reeve, J.D. (1997) Predation and bark beetle dynamics. Oecologia, 112, 48-54.

Safranyik, L., Carroll, A.L., Régnière, J., Langor, D.W., Riel, W.G., Shore, T.L., Peter, B., Cooke, B.J., Nealis, V.G. \& Taylor, S.W. (2010) Potential for range expansion of mountain pine beetle into the boreal forest of North America. The Canadian Entomologist, 142, 415-442.

Schelhaas, M.J., Nabuurs, G.J. \& Schuck, A. (2003) Natural disturbances in the European forests in the 19th and 20th centuries. Global Change Biology, 9, 1620-1633.

Schönenberger, W. (2002) Windthrow research after the 1990 storm Vivian in Switzerland: objectives, study sites, and projects. Forest Snow and Landscape Research, 77, 9-16.

Schroeder, L.M. (2001) Tree mortality by the bark beetle Ips typographus (L.) in storm-disturbed stands. Integrated Pest Management Reviews, 6, 169-175 (publ. in 2003).

Steyrer, G. \& Krehan, H. (2011) Borkenkäfer-Kalamität 2010: Schäden weiterhin sehr hoch. Forstschutz Aktuell, 52, 10-13.

Wallin, K.F., Kolb, T.E., Skov, K.R. \& Wagner, M. (2008) Forest management treatments, tree resistance, and bark beetle resource utilization in ponderosa pine forests of northern Arizona. Forest Ecology and Management, 255, 32633269.

Wermelinger, B. (2002) Development and distribution of predators and parasitoids during two consecutive years of an Ips typographus (Col., Scolytidae) infestation. Journal of Applied Entomology, 126, 521-527.

Wermelinger, B. (2004) Ecology and management of the spruce bark beetle Ips typographus - a review of recent research. Forest Ecology and Management, 202, 67-82.

Wermelinger, B., Duelli, P. \& Obrist, M.K. (2002) Dynamics of saproxylic beetles (Coleoptera) in windthrow areas in alpine spruce forests. Forest Snow and Landscape Research, 77, 133-148.

Wermelinger, B., Epper, C., Kenis, M., Ghosh, S. \& Holdenrieder, O. (2012) Emergence patterns of univoltine and bivoltine Ips typographus (L.) populations and associated natural enemies. Journal of Applied Entomology, 136, 212-224.

Wermelinger, B., Obrist, M.K., Duelli, P. \& Forster, B. (1999) Development of the bark beetle (Scolytidae) fauna in windthrow areas in Switzerland. Mitteilungen der Schweizerischen Entomologischen Gesellschaft, 72, 209-220.

Zuur, A.F., leno, E.N., Walker, N.J., Saveliev, A.A. \& Smith, G.M. (2009) Mixed Effects Models and Extensions in Ecology with R. Springer, New York. 


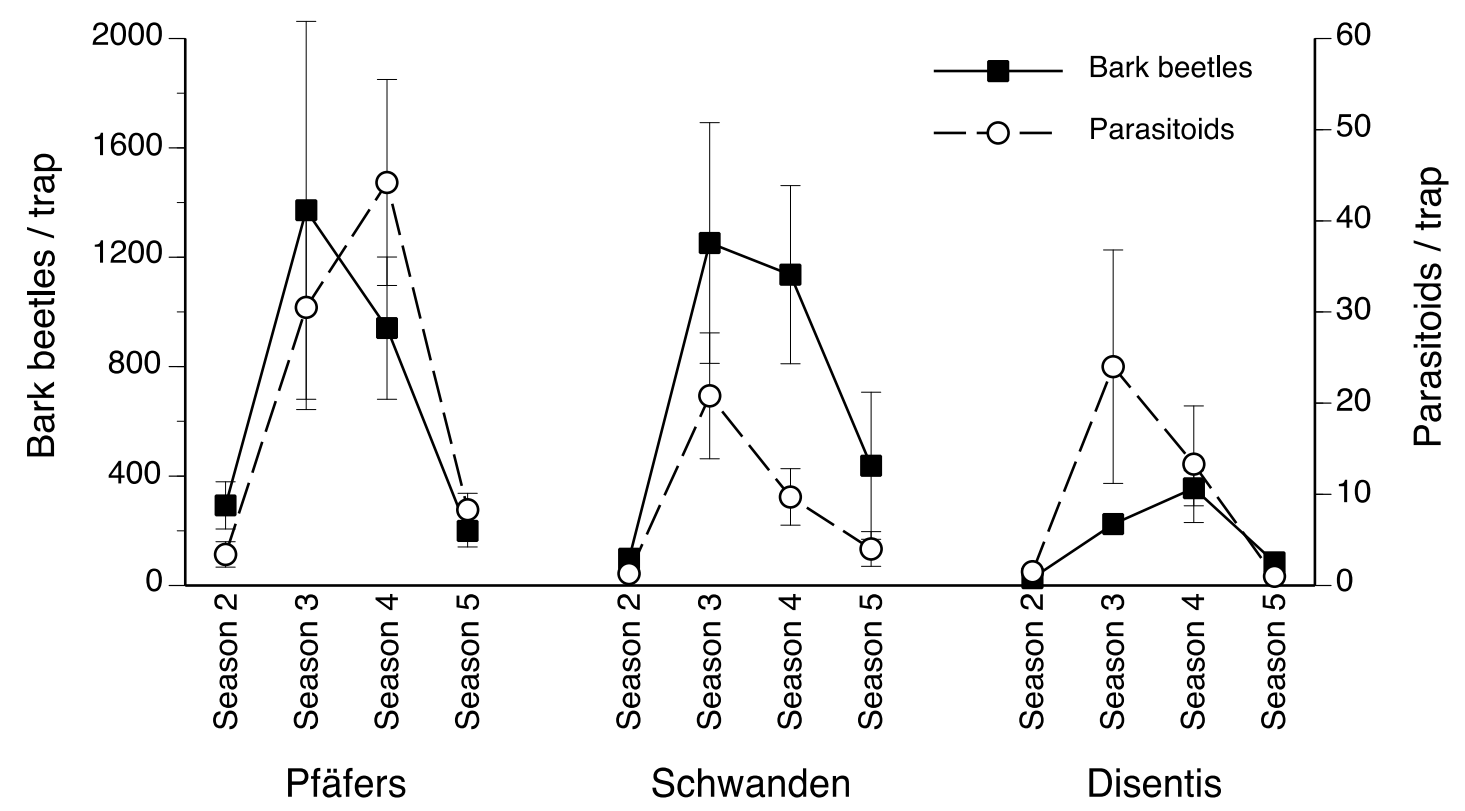

Fig. 1 Annual catches (mean \pm SE) of bark beetles and their associated parasitoids developing in windthrown logs during the first years after the hurricane at three subalpine sites. Note that the catches of a given growing season represent the generation induced in the previous growing season.

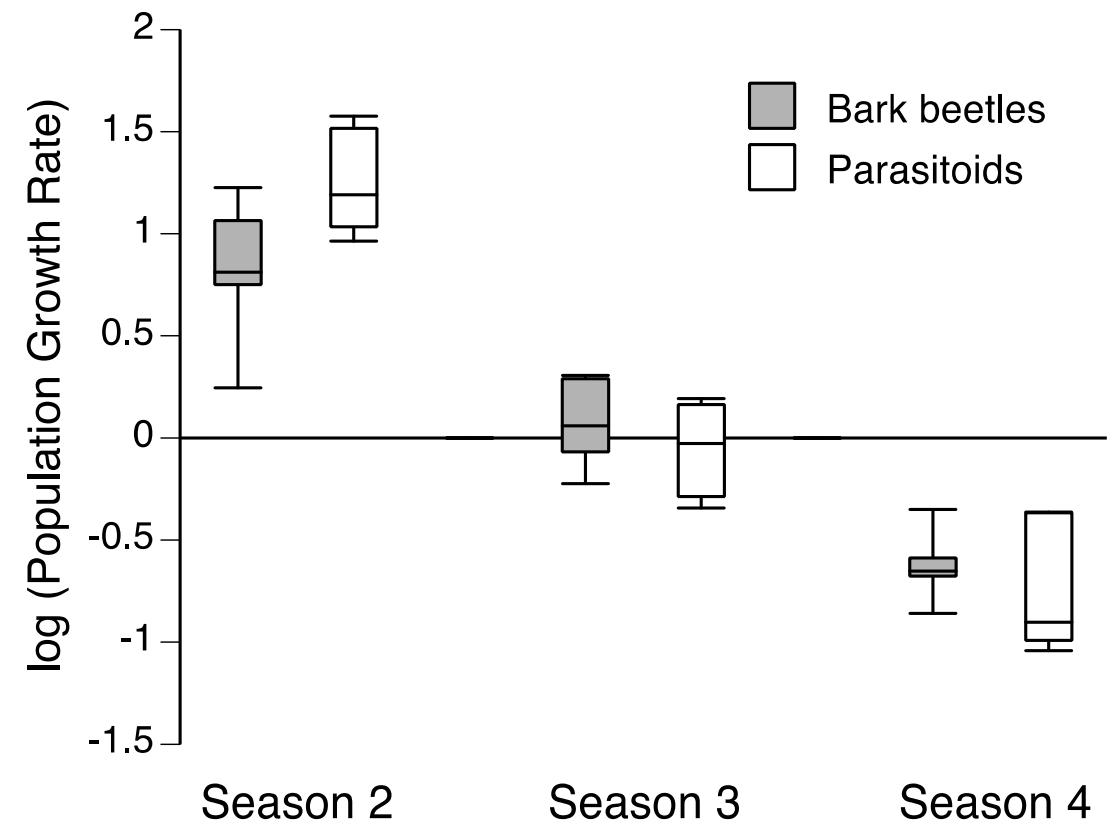

Fig. 2 Population growth rates $\left[\log \left(\mathrm{P}_{t+1} / \mathrm{P}_{\mathrm{t}}\right)\right.$; where $t=$ growing seasons $\left.2-4\right]$ of bark beetles and parasitoids (whiskers at the 10th and 90th percentiles) on windthrow areas (cleared and uncleared). Values $>0$ indicate increasing populations; values $<0$ decreasing populations. 


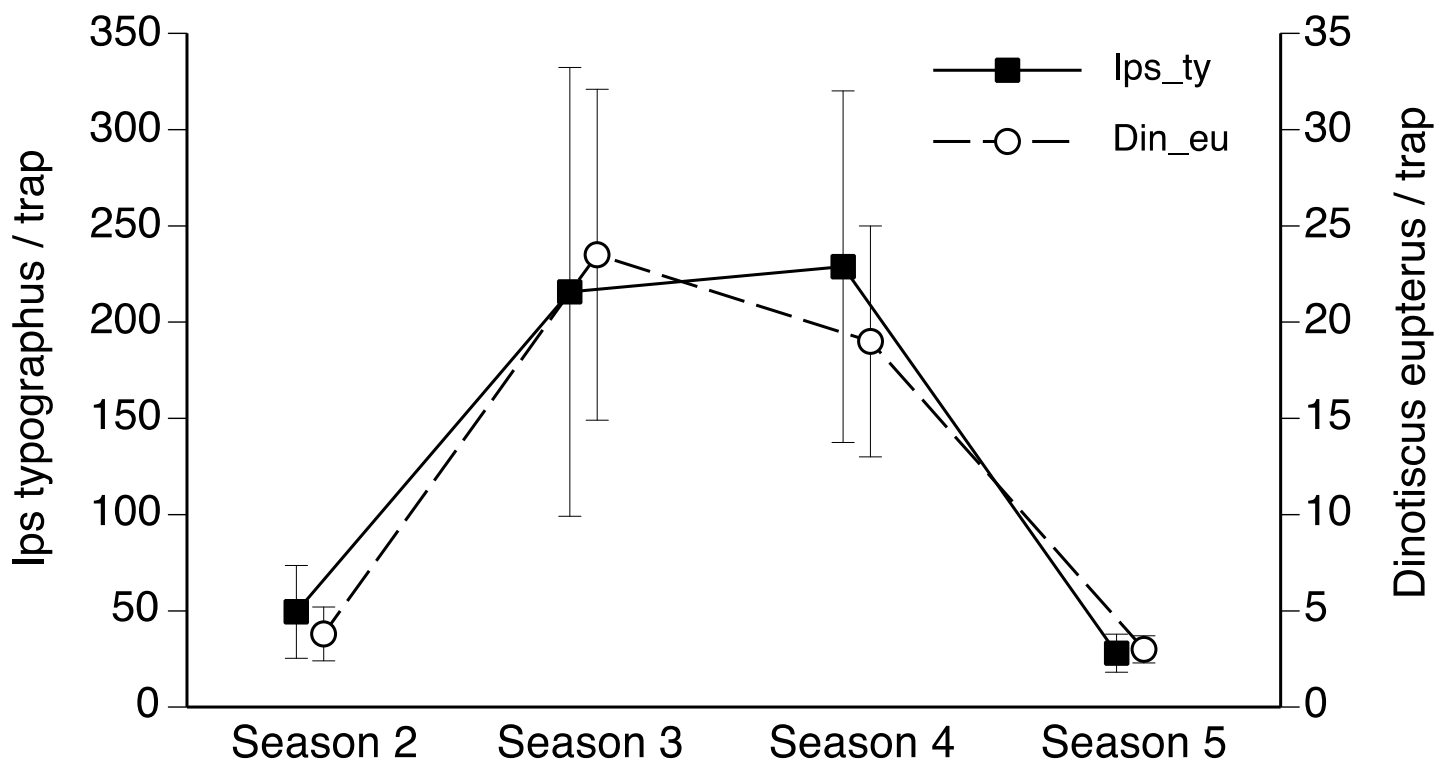

Fig. 3 Annual catches (means \pm SE) of Ips typographus and its most relevant parasitoid Dinotiscus eupterus during the first 4 years after the hurricane (Pfäfers site). Note that the catches of a given growing season represent the flight of the previous growing season's generation.

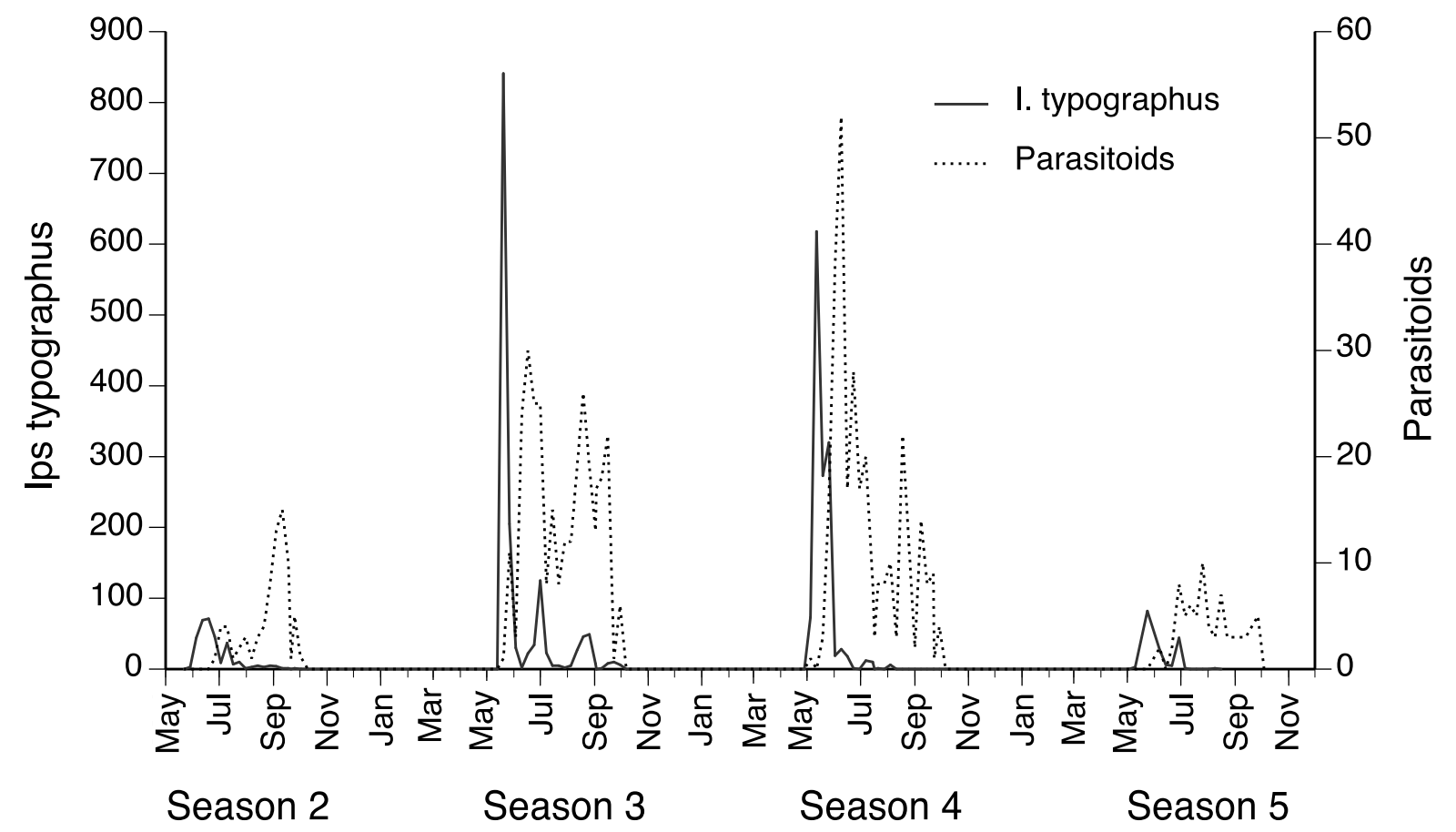

Fig. 4 Four-year flight phenology of the spruce bark beetle I. typographus and bark beetle parasitoids (Pteromalidae) at the Pfäfers site. 

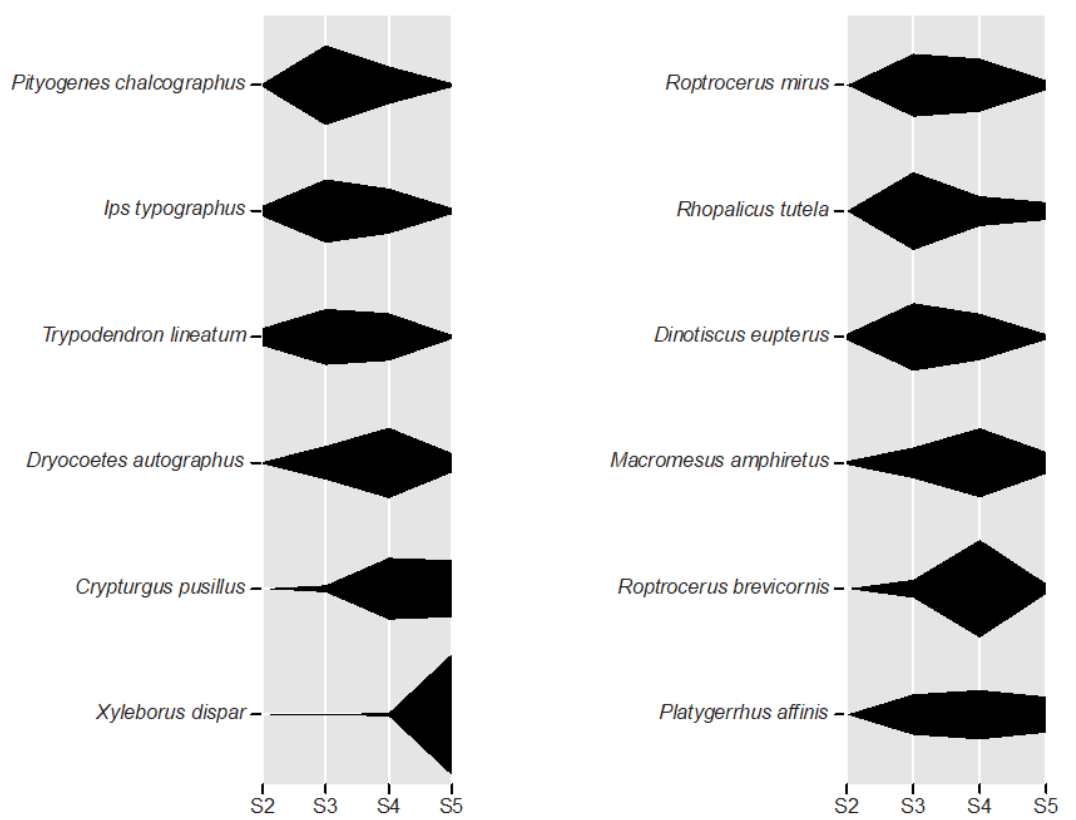

Fig. 5 Temporal succession of bark beetle (left) and parasitoid species (right), based on the relative abundance pattern of each species on the windthrow sites at Pfäfers and Schwanden. Species order does not imply any relationships.

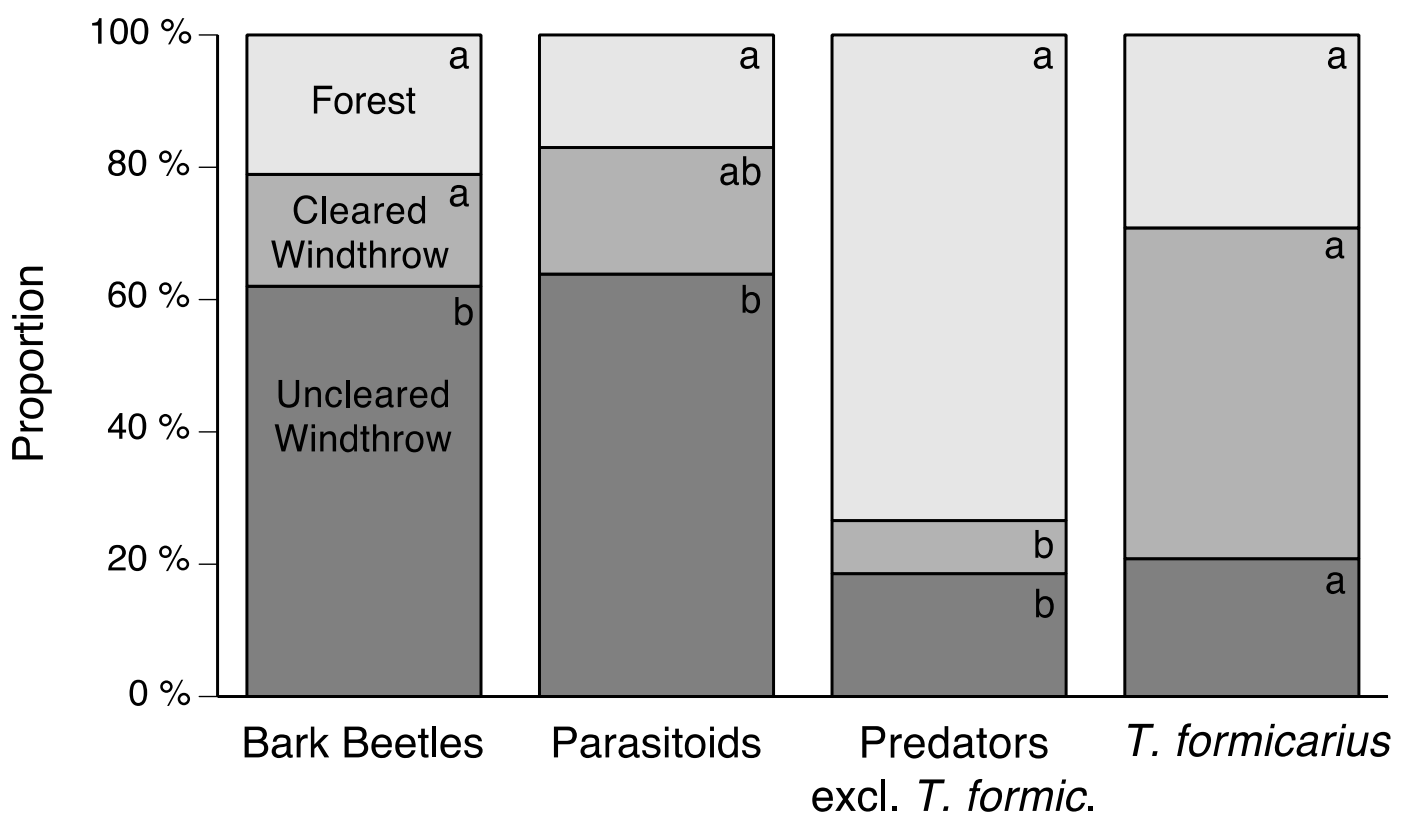

Fig. 6 Relative distribution of bark beetles, parasitoids, and predatory beetles on windthrow areas with (cleared) and without (uncleared) timber harvest, as well as in an adjacent intact forest (Schwanden site, pooled data of the 4th and 5th growing season after the storm). In each column, parts with different letters significantly differ from each other (d.f.= 14, $p<0.05$ ). 
Appendix 1 List of species of bark beetles and of their predatory and parasitoid antagonists together with their abundance in the windthrow areas at three sites during the first years after the storm (S2-S5= growing seasons 2-5). Data on predators are available for the last two seasons only.

\begin{tabular}{|c|c|c|c|c|c|c|c|c|c|c|c|c|}
\hline & \multicolumn{4}{|c|}{ Pfāfers } & \multicolumn{4}{|c|}{ Schwanden } & \multicolumn{4}{|c|}{ Disentis } \\
\hline & S2 & $\mathbf{S 3}$ & \$4 & $\mathbf{S 5}$ & $\mathbf{S}$ & S3 & S4 & S5 & $\mathbf{s 2}$ & S3 & S4 & S5 \\
\hline \multicolumn{13}{|l|}{ PREDATORS } \\
\hline \multicolumn{13}{|l|}{ Cleridae } \\
\hline Thanasimus femoralis (Zett.) & & & 8 & 12 & & & & & & & 1 & 7 \\
\hline Thanasimus formicarius (L.) & & & 22 & 37 & & & 11 & 13 & & & 7 & 2 \\
\hline \multicolumn{13}{|l|}{ Monotomidae } \\
\hline Rhizophagus depressus (F.) & & & & & & & & & & & & \\
\hline Rhizophagus dispar (Payk.) & & & 5 & 1 & & & 41 & 31 & & & 27 & 6 \\
\hline Rhizophagus femugineus (Payk.) & & & 3 & 3 & & & & 2 & & & 5 & 4 \\
\hline Rhizophagus nitidufus (F.) & & & & 1 & & & & & & & & \\
\hline \multicolumn{13}{|l|}{ Nitidulidae } \\
\hline Epuraea angustuda Sturm & & & & 1 & & & & & & & & \\
\hline $\begin{array}{l}\text { Epuraea pygmaed (Gyll.) } \\
\text { Glischrochilus quadriounctatus (L) }\end{array}$ & & & 17 & 1 & & & 3 & 1 & & & & \\
\hline Pityophagus fernugineus (L) & & & 15 & 2 & & & 56 & 76 & & & 6 & 3 \\
\hline \multicolumn{13}{|l|}{ Salpingidae } \\
\hline Rabdocerus foveolatus (Ljungh) & & & 1 & & & & 7 & & & & & \\
\hline Rabdocerus gabrieli(Geh.) & & & 1 & 1 & & & & 3 & & & & \\
\hline Salpingus planirostris (F.) & & & & & & & 2 & 1 & & & & \\
\hline Salpingus nficolfis (L.) & & & 17 & 6 & & & 3 & 11 & & & 1 & 1 \\
\hline \multicolumn{13}{|l|}{ PARASITOIDS } \\
\hline Pteromalidae & & & & & & & & & & & & \\
\hline Dinotiscus eupterus (Walk.) & 15 & 141 & 114 & 18 & 5 & 85 & 49 & 1 & 3 & 103 & 62 & \\
\hline Macromesus amphiretus Walk. & 2 & 17 & 37 & 10 & & & 1 & 2 & & & 3 & \\
\hline Mesopolobus typographi (Rusch.) & & 2 & 3 & & & 1 & & & & & & \\
\hline Pemiphora robusta Rusch. & & & 1 & & & & & & & 1 & 1 & \\
\hline Platygenthus affinis (Walk.) & & 2 & 4 & 2 & & 8 & 10 & 6 & & 2 & 2 & \\
\hline Rhopalicus quadratus (Ratz.) & & & 1 & & & & & & & 2 & & \\
\hline Rhopalicus tutela (Walk.) & & 4 & 5 & 2 & & 12 & & 1 & & & 2 & \\
\hline Roptrocerus brevicomis Thoms. & & 4 & 80 & 6 & & 12 & 7 & 3 & & 1 & 4 & \\
\hline Roptrocerus minus (Wak.) & & 8 & 15 & 2 & & 11 & 1 & 2 & & 11 & 5 & \\
\hline Roptrocerus xydophagorum (Ratz) & & 4 & 4 & 4 & & 4 & 4 & 5 & & & 1 & 1 \\
\hline $\begin{array}{l}\text { Torricobia pityophthori (Bouc.) } \\
\text { Torricobia seitneri (Rusch.) }\end{array}$ & & 1 & 1 & $\begin{array}{l}2 \\
4\end{array}$ & & & & 2 & & & & \\
\hline HOSTS & & & & & & & & & & & & \\
\hline Scolytinae & & & & & & & & & & & & \\
\hline Cryphalus abietis (Ratz) & 547 & 1204 & 741 & 344 & 299 & 635 & 757 & 45 & 71 & 70 & 93 & 10 \\
\hline $\begin{array}{l}\text { Cryphalus intermedius Fenr. } \\
\text { Cryphalus piceae (Ratz.) }\end{array}$ & & $\begin{array}{c}11 \\
8\end{array}$ & $\begin{array}{c}6 \\
73\end{array}$ & $\begin{array}{l}1 \\
8\end{array}$ & & & & & & & & \\
\hline Cryphalus saltuarius Weise & & 20 & 14 & & & & & 1 & & 4 & 7 & 8 \\
\hline Crypturgus cinereus (Herbst) & & & & & & 1 & & & & & & \\
\hline Crypturgus hispidutus (Thoms.) & & 2 & 2 & 8 & & 1 & 1 & 3 & & & 1 & 2 \\
\hline Crypturgus pusittus (Gyll.) & 2 & 22 & 123 & 38 & 3 & 159 & 1504 & 1441 & & 4 & 15 & 12 \\
\hline Dendroctonus micans (Kug.) & 1 & & 3 & 1 & 1 & 2 & 1 & 2 & & 4 & 2 & 1 \\
\hline Dryocoetes alni (Georg) & 5 & & 3 & & & & & & & & & \\
\hline Dryocoetes autographus (Ratz) & 31 & 112 & 474 & 155 & 40 & 1292 & 2412 & 698 & 4 & 139 & 63 & 148 \\
\hline Dryocoetes hectographus Reitt. & & 20 & 41 & 19 & & 49 & 27 & 10 & & 11 & 1 & 6 \\
\hline Emoporicus fagi (F.) & & & & 1 & 3 & 1 & & 11 & & & & \\
\hline Hydastes ater (Payk.) & & & & & & & & 2 & & & & 1 \\
\hline Hylastes attenuatus Erichs. & & & & & & & & & & 2 & & \\
\hline $\begin{array}{l}\text { Hylastes cunicularius Erichs. } \\
\text { Hylastes opacus Erichs. }\end{array}$ & 151 & 278 & 302 & 121 & 104 & $\begin{array}{c}2278 \\
1\end{array}$ & 402 & 406 & 3 & 270 & 268 & 174 \\
\hline Hylesinus fraxini (Panz) & & & & 1 & 18 & & & 1 & & & 1 & \\
\hline Hyturgops glabratus (Zett.) & & 3 & & 1 & & 4 & & 3 & & 5 & 1 & 2 \\
\hline Hyturgops palliatus (Gyll.) & 8 & 11 & 115 & 18 & 17 & 1133 & 87 & 24 & 2 & 11 & 302 & 3 \\
\hline Ips amitinus (Gyll.) & 1 & & 1 & 3 & 4 & 82 & & 4 & 1 & 14 & 27 & 2 \\
\hline Ips typographus (L) & 297 & 1294 & 1373 & 168 & 117 & 914 & 198 & 46 & 3 & 65 & 77 & 18 \\
\hline Orthotomicus laricis (F.) & 6 & 15 & 50 & & 18 & 172 & & & & 16 & 28 & 3 \\
\hline $\begin{array}{l}\text { Phloeotribus spinulosus (Rey) } \\
\text { Pityogenes bidentatus (Herbst) }\end{array}$ & 22 & $\begin{array}{c}19 \\
1\end{array}$ & 38 & 41 & 9 & 9 & 1 & 7 & 8 & 9 & 8 & 14 \\
\hline Pityogenes chakcographus (L) & 273 & 4077 & 1360 & 125 & 98 & 3730 & 2343 & 286 & 36 & 527 & 440 & 28 \\
\hline Pityogenes conjunctus (Reitt.) & 20 & 60 & 37 & 24 & 6 & 28 & 277 & 15 & 2 & 19 & 15 & 5 \\
\hline Pityophthorus pityographus (Ratz) & 36 & 225 & 172 & 75 & 22 & 95 & 137 & 53 & 9 & 97 & 74 & 57 \\
\hline Polygraphus poligraphus (L.) & 14 & 34 & 12 & 6 & 1 & 1 & & 4 & & 7 & & 2 \\
\hline Taphrorychus bicolor (Herbst) & & & & & & 1 & & 1 & & & & \\
\hline Tornicus minor (Hart.) & & & 1 & & & & & & & & & \\
\hline Trypodendron domesticum (L) & & & & & & 3 & & 2 & & & & \\
\hline $\begin{array}{l}\text { Trypodendron lineatum (OFv.) } \\
\text { Xyleborus dispar (F.) }\end{array}$ & 336 & 813 & 704 & 36 & 9 & $\begin{array}{c}961 \\
1\end{array}$ & $\begin{array}{c}280 \\
3\end{array}$ & $\begin{array}{c}54 \\
116\end{array}$ & 22 & $\begin{array}{l}47 \\
25\end{array}$ & $\begin{array}{c}664 \\
40\end{array}$ & $\begin{array}{l}2 \\
8\end{array}$ \\
\hline Xylechinus pilosus (Ratz) & 6 & 3 & 1 & 3 & 8 & 120 & 12 & 288 & & & 2 & 2 \\
\hline Xylosandrus germanus (Blandf.) & & & & & & & & & & & 2 & \\
\hline
\end{tabular}

